\title{
The Girlfriend Getaway Market: Segmenting Accommodation and Service Preferences
}

Catheryn Khoo-Lattimore ${ }^{\text {a }}$, Girish Prayag ${ }^{\text {b }}$

a Department of Tourism, Sport \& Hotel Management, Griffith Business School, Griffith University, 170 Kessels Road, Nathan, QLD 4111, Australia

Email: c.khoo-lattimore@griffith.edu.au

and

School of Hospitality, Tourism and Culinary Arts, Taylor's University Lakeside Campus, 47500

Subang Jaya, Malaysia

b Department of Management, University of Canterbury, Private Bag 4800, Christchurch, New Zealand.

Email: girish.prayag@canterbury.ac.nz

*Corresponding Author : : Catheryn Khoo-Lattimore

Email: c.khoo-lattimore@griffith.edu.au

Acknowledgement: This manuscript was prepared during scholarship funded by The Bureau of Educational and Cultural Affairs of the United States Department of State; and the MalaysianAmerican Commission on Educational Exchange under the Fulbright Visiting Scholar Award. 


\title{
The Girlfriend Getaway Market: Segmenting Accommodation and Service Preferences
}

\begin{abstract}
The main objective of this paper is to segment the accommodation and service preferences of females who participate in girlfriend getaways (GGA). A sample of 540 female travelers revealed five distinct clusters of preferences based on the importance scores assigned to hotel attributes. The clusters are then profiled on their performance scores on hotel attributes and demographic characteristics. The results indicate that the GGA market is heterogeneous in its accommodation and service preferences but homogeneous in its demographic characteristics. Accommodation suppliers and marketers must recognize the growing importance and profitability of this segment of the female traveler market. Implications for product development, targeting and positioning strategies, and service enhancements for this market are suggested.
\end{abstract}

KEYWORDS: Female, women, segmentation, girlfriend getaway, hospitality, hotel attributes, Malaysia

\section{Introduction}

Female travelers constitute a significant segment of the leisure travel and tourism industry (Ćurcic, Zakic, \& Galantić, 2009). The female market is significant both in terms of its present and projected size. Fifty-one percent of American travelers, for example, are females, with a staggering prevalence for leisure (72\%). The 2012 Female Travel and Lifestyle Report reveals that nearly two out of three people in their survey of 5000 women in Australia (not necessarily Australians) have travelled overseas (Gentle, 2012). Female travelers also possess formidable financial strength (Silverstein \& Sayre, 2009) by controlling over \$20 trillion in 
world-wide spending (Kent, 2010) and making $80 \%$ of the decisions on travel and tourism (Bond, 2011). Unsurprisingly, much of the existing tourism research attempts to better understand women as travelers. Past studies have considered women travel decision-making (Candice Harris \& Wilson, 2005; Kerstetter \& Pennington-Gray, 1999); travel motivations (Chiang \& Jogaratnam, 2006; McGehee, Loker-Murphy, \& Uysal, 1996; McNamara \& Prideaux, 2010); travel patterns (Barlés-Arizón, Fraj-Andrés, \& Matute-Vallejo, 2010; Nichols \& Snepenger, 1988); and travel behavior (Mieczkowski, 1990). In studying women travelers, scholars have utilized theories related to perception (Westwood, Pritchard, \& Morgan, 2000), identities (Heimtun, 2012), constraints (Khan, 2011; Wilson \& Little, 2005), safety and security (Sham, Soltani, Sham, \& Mohamed, 2012; Wilson \& Little, 2008), the meaning of travel (Wilson \& Harris, 2006), and life cycle (Gibson, Berdychevsky, \& Bell, 2012). Within the female travel market, scholars have also investigated niche markets such as solo woman travelers (Chiang \& Jogaratnam, 2006; Jordan \& Gibson, 2005; McNamara \& Prideaux, 2010; Wilson \& Little, 2008), senior women travelers (Stone \& Nichol, 1999), educated women travelers (PenningtonGray \& Kerstetter, 2001), women cruisers (Jennings, 2005), and more extensively, businesswomen travelers (Alamdari \& Burrell, 2000; Foster \& Botterill, 1995; Lutz \& Ryan, 1993; McCleary, Weaver, \& Lan, 1994; Newth, 2011; Sammons, Moreo, Benson, \& Demicco, 1999; Smith \& Carmichael, 2007). These studies presuppose that the female travel market is heterogeneous and segmentation allows the identification of unique characteristics, attitudes and behaviors.

A growing trend in women's travel that has received scant attention is the phenomenon of all female leisure-travel groups, or what is being called girlfriend getaways (GGAs). The GGA 
market generally refers to female travelers who are holidaying with other females including friends, family members, colleagues, sporting team members, and fellow members from organizations they belong to (Gibson, Berdychevsky and Bell, 2012). In terms of growth stage, the current GGA market can be paralleled to the gay segment prior to the 1980s when few dependable statistics existed. As with any new emerging markets, the exact size and worth of the GGA segment cannot be accurately ascertained. However, one study at least points to its potential, for example, in the U.S. alone, the girlfriend getaway market represents four percent of all U.S. travel spending which has developed into a \$6 billion segment (AAA, 2007). The study also found that there has been an increase in women taking girlfriend getaways, from $30 \%$ in 2004 compared to $40 \%$ in 2007 , and that most girlfriend getaways consist of two to three women. Another study by American Express Travel found that two thirds of their 246 travel agents reported a growth in "girls-getaways" and showed that women traveling together are now seeking for more active and luxurious vacations (Wilkeming, 2007). The American Resort Development Association report of 2010 suggests that 38 percent of women have taken a GGA in the U.S. and 63 percent plan on taking one in the next two years (Anon, 2010). Although there is insufficient research on consumption patterns amongst this segment, a few writers have recognized the GGA trend with reports of its members being, " $72 \%$ married, $60 \%$ ranging between the ages of 35 and 45 and 88\% have children less than 18 years old” (Cavallari, 2008, p. 8). Other reports reveal that women who take girlfriend getaways range from "Midwest mothers and daughters to affluent businesswomen to low income girls” (Euromonitor, 2010, p. 3). Hence, this segment may comprise a variety of 'niches' that would be worthwhile studying within and outside of the US. 
More recently, mainstream tourism and hospitality marketers have begun targeting this emerging segment of GGAs. For example, Tripadvisor published its list of the top ten girlfriend getaway destinations in 2010. Other tourism establishments have followed suit with their own lists of the best GGAs must-do’s and must-go’s (Friesen, 2013; Harranek, 2014; Ward, 2013). The number of tour operators that concentrate only on all-women's travel has increased from 21 in 2007 to 49 in 2009 (Bond, 2007, 2009). In addition, hotels not traditionally focused on women travelers, have begun to target the all-female travel segment with new products aimed at the GGA market (e.g., The Grand Hotel’s 2014 Girlfriend Getaway Package in Michigan, USA). Non-academic literature on GGAs is on the rise (e.g. Bond, 2007, 2009; Getaways, 2008; Grout, 2003, 2005; Kasanicky, 2009; Laing \& Butterfield, 2002). In fact, Grout (2005) in the preface of her second edition wrote,”...we came out with the book in 2003 about the same time as the Los Angeles Times, the Detroit Free Press, Oprah Winfrey and lots of other well-known authorities started recognizing the trend. I ended up getting interviewed a lot” (p. i). It is clear thus far that there is awareness of GGAs being a rising segment, having already attracted the attention of media and the wider tourism industry.

Despite Asia-Pacific tourism being the fastest growing in the world in 2012 (UNWTO, 2013), academic and non-academic research on the GGA market in this region is limited. However, a Mastercard International study has revealed the rising trend of mother-daughtergranddaughter travel in Asia-Pacific (Mastercard, 2005) and anecdotal evidence from the hospitality sector suggests that the GGA segment is valued by tourism and hospitality businesses. For example, the Legend group of hotels in Malaysia has a "Lady Programme" that caters to female guests (Anon, 1997). Other hotels such as 'Thistle' and 'Crown Princess' in Malaysia 
both have 'ladies' only floor (Loh, 2009). Within this context of Malaysia, academic knowledge on the attitudes, preferences and behaviors of the GGA market is non-existent. Hence, the study aims to (1) segment the accommodation and service preferences of women in the girlfriend getaway market and (2) identify 'niche' segments within the GGA market based on preferences and demographic characteristics. By doing so, the study contributes to the hospitality literature in two main ways. First, it identifies the most salient accommodation attributes for the GGA market, thereby providing both scholars and practitioners an insight into the preferences of this female travel segment. Existing studies are mainly driven by the attitudes and behavior of female business travelers and their accommodation preferences (Lutz \& Ryan, 1993; McCleary et al., 1994; Phadungyat, 2008; Sammons et al., 1999). Second, by segmenting the GGA market, this study is the first to identify profiles of 'niches' within the GGA market that may be of interest to both large and small accommodation providers thereby extending academic knowledge on the female-only travel groups.

\section{Literature Review}

\subsection{Segmentation Theory}

Segmentation is ubiquitous in the hospitality and tourism literature (Frochot \& Morrison, 2001; Prayag \& Hosany, 2014). It consists of dividing a market into smaller and homogeneous groups based on the assumption that customers are heterogeneous and that a differentiated market offering can satisfy them (Kruger, Saayman, \& Ellis, 2011). Identifying new and/or underrepresented markets segments is a managerial priority to grow the potential customer base and develop relevant marketing strategies in a cost-effective way while continuing to focus on existing customers (Morrison, 1996; Vellas \& Becherel, 1999; Weaver \& Oppermann, 2000). No 
absolutely "correct" segmentation method exists (Tkaczynski \& Rundle-Thiele, 2010) and the researcher must find the best segmentation method to capture the hidden structure in the data set (Prayag \& Hosany, 2014). Several studies segment the female consumer market to understand decision-making styles (Bakewell \& Mitchell, 2003), shopping orientation (Shim \& Kotsiopulos, 1993), and women's lifestyles and consumption behavior (Tai \& Tam, 1997) but comparatively the tourism and hospitality literature remains thin on segmentation of female travelers beyond the business travel market as discussed below.

\subsection{Segmenting the Female Traveler Market}

With respect to female travelers, Smith and Carmicheal (2006) segmented the domestic female business travelers in Canada and found three distinct types of women. The three groups differed in terms of demographics, travel patterns and travel activities. More specifically, the segment which mixes business travel with pleasure tend to be highly educated women who take infrequent but longer trips and spend more than $\$ 500$ per trip. These women, who are mostly self-employed, tend to visit friends or relatives and undertake tourism-related activities, particularly those in rural settings. Meanwhile, Newth (2009) also found three segments of American female business travelers based on psychographic characteristics - the connective, the productive and the empowered. She found that the most important psychographic variables which differentiated the three groups are the need to connect with others, the feeling of empowerment and the feeling of being industrious.

More closely aligned with the purpose of this study, Pennington-Gray and Kersetter (2001) segmented educated female travelers according to the benefits they sought from their 
travel and reported three possible types of educated women - those who travel for relaxation, those who seek family and social interaction in their travels, and those who thrive on action and adventure. Industry reports on the GGA market suggest that such travelers tend to participate in specific activities such as eating and dining out, shopping, spa visits and going to the beach/pool (AAA Girlfriend Travel Research, 2007; Bond, 2009). Grout (2005) lists dining, shopping, road trips, sports, and indulgence in spa and luxury as typical girlfriend getaway undertakings. Kasanicky (2009) suggests that culinary lessons, art classes, volunteering vacations and attending festivals or events are other possible activities relevant to the GGA market. These preferences for specific activities and services suggest the need to understand the behavior of GGA market in more depth to allow for product development and service customization. Yet, without an understanding of the accommodation preferences of female travelers, including the GGA market, it is difficult for hoteliers to develop customized holiday packages, improve targeting and positioning strategies.

\subsection{Accommodation Preferences of Female Travelers}

Although no study has been conducted on the accommodation preferences of female leisure travelers, insights can be gained from studies on female business travelers (Lutz and Ryan, 1993; Sammons et al., 1999; Phadungyat, 2008). Lutz and Ryan (1993), in studying the differences between male and female preferences towards hotel services, found that businesswomen placed higher priorities than men on safe and secure car parks and the ability to feel comfortable when dining in hotel restaurants. Surprisingly, females in their study were indifferent to hotels’ offerings of women-only floors, female toiletries and feminine décor. McCleary et al. (1994) pointed out marked distinctions between male and female business 
travelers in the ways hotel products are consumed. They noted that while men placed importance on business facilities such as office space and fax machine, women were more concerned with the hotel's safety and security features such as dead bolt door locks, peep hole, surveillance camera, chain lock, bright hallway and parking area lighting. Sammons et al. (1999) study of female business travelers' preferences for accommodation revealed that women-only floor, feminine décor (such as pastel-colored rooms) and female toiletries (bubble bath and nail polish remover) were unimportant. Instead, they placed high importance on hotel cleanliness and security provisions. Phadungyat (2008) confirmed that "safety and security facilities, especially ‘electrical keycard', 'bright hallway', ‘sprinkler system', and ‘closed circuit television' are important factors for businesswomen in their selection of serviced apartments"(p. 45). The importance of safety and security as a choice criterion is consistent across several studies on women travelers.

Interestingly, of the limited studies on women accommodation preferences, the majority focuses on Western women. An exception is the study of Ariffin and Maghzi (2012) that compared Malaysian and non-Malaysian tourists on the influences of gender on expectation level of hospitality in four and five star hotel services. Their study revealed that male customers were more concerned with the behavior of employees compared to their female counterparts. In a Muslim tourists context, Eid and El-Gohary (2015) showed the influence of religiosity on male and female tourism choices, including its impact on the physical attributes and services offered by accommodation providers. In the broader services marketing literature, gender differences on service evaluations are noted for product assessment (McDaniel \& Kinney, 1998) and satisfaction judgments (Dubé \& Morgan, 1998). Yet, in evaluating hotel and restaurant settings, 
Mattila (2000) failed to demonstrate the impact of gender on service encounter evaluations. Hence, contradictory evidence exists on whether females evaluate services differently from males in general and when such differences exist, they may be country/culture dependent.

\subsection{Accommodation Preferences of the GGA Market}

Although earlier studies have delineated the accommodation preferences of female business travelers (Lutz and Ryan, 1993; McCleary et al., 1994; Sammons, Moreo, Benson \& Demicco, 1999; Phadungyat, 2008), very few studies (Gibson, Berdychevsky and Bell, 2012) focus on women who travel with other women. The GGA market is a different type of female traveler, for three reasons. First, compared to women who travel solo, for business, with their spouses, and with families, the motivation of women going on girlfriend getaways is mainly friendship. This is true for women of all ages and at varied life-stages (Gibson, Berdychevsky and Bell, 2012). The appreciation for friends as a motivation for holidays has been alluded to in leisure and sociology research (e.g. Glover \& Parry, 2008; Green, 1998; Kleiber, Hutchinson, \& Williams, 2002) as well as sports studies (Lenskyj, 1994). Lenskyj (1994) for instance found that female athletes tend to enjoy and value the social interaction during sporting events. While socialization and kinship as a motive for travel is well-examined in the tourism literature (Crompton \& McKay, 1997; Kim \& Prideaux, 2005), this motive has never been examined in the

context of women travelling with other women. The central role of friendship in girlfriend getaways have been found to impact holiday experiences (Berdychevsky, Gibson and Bell, 2013). 
Second, the literature highlights the need for women to be relieved of their fear and frustrations with the "male gaze" during their solo holidays (C Harris \& Ateljevic, 2003; Pritchard \& Morgan, 2000). The girlfriend getaway could possibly be a materialization of these needs, which should be carefully considered by accommodation providers in their delivery of hotel amenities and services. For example, women on girlfriend getaways who travel in the security of their groups may not place safety issues as high a priority as women who travel solo for leisure and business purposes. Finally, women perceive getaways with their female friends differently from the travels they do on their own or the holidays they take with other people. Conceptualized in what Graburn (1983) terms as rites of passage tourism, GGAs are taken to mark one's transition from one stage to another. This is confirmed in Gibson, Berdychevsky and Bell (2012)'s study where they found women in their adolescence, early adulthood, middle adulthood, and later adulthood (ranging from age 21 to 87) take girlfriend getaways to signify important transitions such as graduation, weddings, illness and death of a spouse. This recent finding bears implications on the existing literature on female preferences for accommodation services. The fact that women of all ages tend to participate in GGAs may also suggest that demographic segmentation alone may be insufficient to understand this market.

\section{Method}

\subsection{The Survey Instrument}

To segment the accommodation and service preferences of female only leisure groups, the survey instrument was built from multiple phases of qualitative inquiries. First, a list of 77 hotel attributes of importance to female guests was generated from the literature (Lutz and Ryan,

1993; McCleary et al., 1994; Phadungyat, 2008; Sammons et al., 1999). This list was compared 
to accommodation and service requirements identified from the in-depth interviews of 13 Malaysian women who had been on GGA in February 2012. The women were asked to list features of the accommodation that they had particularly enjoyed during their GGAs. They were also asked to make recommendations to accommodation providers on what they might like to see in their future GGA stays. The interviews yielded nine additional amenities and services not identified from the literature. For example, interviewees expressed the needs for manicure collections and the need for hotels to arrange for sightseeing in locations that interviewees were not familiar with. The latter was conceptualized in the survey instrument as, "Hotel offers free transport to nearby shopping malls”. Two further examples of items which were uncovered from the interviews and added to the list were the hotel's offer of shopping vouchers and discounts for massages and spa treatments. These additional service requirements were added to the list and implemented in six hotel rooms as part of an experiment. The hotel rooms were equipped with as many different items on the list as possible, after which three groups of four women were invited to experience the "girlfriend getaway" rooms over a period of two days. At the end of their stay and upon checkout, the women were interviewed as part of three focus groups. In all three focus groups, we asked the same questions as in the initial study - what they have particularly enjoyed and what improvements they would like to make. Their responses were used to refine the list into 18 specific items that would be of relevance to the GGA market irrespective of types of accommodation.

As a result, the survey instrument consisted of various sections. The first section measured the "importance" of various attributes covering four broad areas of accommodation and service requirements: Safety and Security (4 items); Room Amenities (7 items); Food and 
Beverage (2 items); and Activities/Entertainment (5 items). Participants were asked to indicate how important each hotel attribute was to them when they go on girlfriend getaways on a 5-point Likert scale, ranging from 1 (not at all important) to 5 (extremely important). The second section measured the performance of 15 attributes that were identified as problematic for women guests on a GGA trip. These items were identified from the in-depth interviews and focus groups only. The list was measured on a performance scale anchored on 1 (Very Bad) and 5 (Very Good).The last section measured several demographic (e.g., age, education level, nationality and marital status) and trip characteristics (e.g., previous stay, number of nights stayed, membership tenure with the group, and main purpose of visit).The instrument was piloted on 50 female guests that stayed with other women only at the same hotel where the experiment was carried out, after which minor modifications were made.

\subsection{Data Collection and Analysis}

Data were collected over a period of two months (May/June 2013). Respondents were recruited from a resort's membership data base which at the time of data collection consisted of 4.84 million members, of which 2.24 million were females. The resort has over 8,000 rooms spread over multiple properties with different star ratings in Malaysia and Singapore. From the list of 2.24 million females, two criteria were used to include members in the sampling frame. First, only female members that are known to have shared their rooms with other female guest(s) only between February and March 2013 were included. Second, the female members were travelling mainly for holiday purposes. These criteria yielded 3,856 females that had holidayed in hotels of the group in Malaysia (96.7\%) and Singapore (3.3\%). The survey instrument was emailed to all respondents $(2,086)$ that had a recorded and valid email address in the database. In 
order to encourage participation, respondents were told that they will be entered into a prize draw for a two-night complimentary stay at the resort. The survey resulted in 540 useable questionnaires for data analysis purposes, excluding outliers. While recent studies (e.g. Dolnicar, Grün, Leisch, \& Schmidt, 2014) have expressed concerns about sample sizes used in segmentation studies, this dataset suffers from low contamination by noisy variables (a situation whereby a substantial amount of variables is not relevant for the clustering structure). All the variables used for clustering were selected following the rigorous process of item generation and refinement described earlier. Accordingly, the sample size is deemed to meet the requirements for data-driven segmentation procedures.

A three step procedure was employed to analyze the data. In conformance to data driven segmentation procedures (Dolnicar, 2002; Dolničar, 2004), Ward's clustering method with Euclidean distances was used initially to identify possible clustering solutions. Instead of the factor-cluster procedure commonly used in segmenting tourism markets (Park \& Yoon, 2009; Prayag, 2010; Sarigöllü \& Huang, 2005), the raw scores were used to derive the segments. The factor-cluster procedure has been heavily criticized in both marketing and tourism literatures (Dolnicar \& Grün, 2008; Tuma, Decker, \& Scholz, 2011) for: (i) transformation of the data space that does not reflect the original items measured; and (ii) conducting factor analysis before clustering leads to approximately $40-50 \%$ of the original information lost (Dolnicar, 2007; Dolnicar \& Grün, 2008). Also, the importance of an object is a more stable attitudinal construct than its performance (Lounsbury \& Hoopes, 1988). Accordingly, the 18 importance items were used for clustering rather than the performance items. Thereafter, discriminant analysis was used to confirm the validity of the chosen clustering solution. In the second step, the performance 
items were used to profile the clusters after factoring the 15 items. In the final stage of the analysis, the identified segments were profiled on the basis of demographic and trip characteristics.

\section{Findings}

\subsection{Sample Profile}

The survey polled a range of age groups with more than a quarter of the sample (25.7\%) being aged between 21 to 30 years old. More than half of the sample (54.7\%) was of Malaysian nationality. Almost an equal number of females described their marital status as 'single' (44.7\%) and 'married' (43.5\%). The sample was well educated with $83 \%$ of respondents having at least completed secondary education and $96.9 \%$ of respondents had stayed in a hotel of the group before. A more detailed sample profile is provided in Table 1.

\section{-TAKE IN TABLE 1-}

\subsection{Cluster Identification}

Initially, a non-hierarchical $K$-means clustering algorithm developed two, three, four and five cluster solutions. An examination of group membership, group sizes, and the associated dendograms indicated that the five cluster solution was more appropriate. The chosen solution offered the most meaningful, interpretable and distinguishable segments (Park \& Yoon, 2009; Prayag, 2012), reflecting a 'commonsense' segmentation approach (Dolničar, 2004) . From Table 2, Cluster I $(n=162)$ is the largest cluster with $30 \%$ of respondents and labeled 'Safety Conscious' female travelers. They assigned above average importance levels to all of the safety 
and security items except for item 2. This cluster assigned low average importance to all other items except for items 5, 12, 14 and 15 . Cluster II $(n=131)$ with $24.3 \%$ of respondents places above average importance to all safety and security items, except for item 2 . They assign above average importance to room amenities items, except for item 5. They assign lower mean importance to the food and beverage and activities/entertainment items in comparison to Cluster I. They were labeled 'Safety and Amenities Driven'. Cluster III (n=37) was the smallest cluster with $6.8 \%$ of respondents. They assigned lower mean importance levels to all safety and security items in comparison to Clusters I and II. However, in comparison to Clusters I and II on average they assign higher importance levels to food and beverage items. They were thus labeled 'Food and Beverage Driven'. Cluster IV (n=113) with 20.9\% of respondents was labeled 'Safety and Activities Driven’. This group assigned above average levels of importance to safety and security items, except for item 2 but rated all of the room amenities items below average, except for items 5, 10, and 11. In comparison to Clusters I, II and III, on average they assigned higher levels of importance to activities and entertainment items. Cluster V ( $\mathrm{n}=97)$ with $17.9 \%$ of respondents was labeled 'Desirables'. In comparison to all other clusters, on average they had the highest importance ratings of all items.

-TAKE IN TABLE 2-

Discriminant analysis was used to ascertain the reliability of the five-cluster solution. Table 3 shows that four statistically significant discriminant functions (DF) were extracted, explaining all of the variance in the clusters. The canonical correlation between all four functions is high and significant at the $1 \%$ level, suggesting that a relationship exist between clusters and 
the extracted discriminant functions. Generally, the chosen cluster solution should produce the highest percentage of correct classification of respondents in their respective groups (Park and Yoon, 2009; Prayag, 2012; Prayag and Hosany, 2014). In this case, the classification matrix showed that $96.3 \%$ of respondents were correctly classified instead of the $95.7 \%$ and $94.8 \%$ correct classification for a three and four-cluster solution respectively.

\section{-TAKE IN TABLE 3-}

\subsection{Cluster Profiling by Hotel Attribute Performance}

The 15 items identified from the in-depth and focus groups on problematic areas of service offer by hotels were used to profile the clusters. Prior to profiling the clusters on these hotel attribute performance, factor analysis was used to reduce the 15 items to a few dimensions. Using the usual criterion of KMO statistic (0.726) greater than 0.7, significant Bartlett's test of sphericity $\left(\chi^{2}=3686.2 ; \mathrm{p}<0.001\right)$, eigenvalues greater than one, factor loadings in excess of 0.4 , and varimaxrotation, revealed the existence of five factors explaining $73.2 \%$ of total variance. The five factors were labeled: F1 (Hotel Room Amenities); F2 (Safety and Security); F3 (Food and Beverage); F4 (Personal Touch); F5 (Augmented Services). Cronbach’s alpha values for all factors met the minimum requirement of 0.7 for internal reliability and consistency (Hair et al., 2005). 
ANOVA results with Schéffe post-hoc comparison of means on composite scores of the five performance factors and cluster membership, indicated significant differences between several of the clusters (see Table 5). On average, Cluster I ( $M=2.56)$ rated Factor one (F1) 'Hotel Room Amenities' slightly better than Cluster II $(M=2.10)$. On Factor two (F2), significant differences existed on hotel performance scores between Clusters III, IV and V. Cluster V $(M=2.97)$ on average rated 'Safety and Security' performance slightly better than Clusters IV $(M=2.92)$ and III $(M=2.24)$. Factor three (F3) was rated significantly different by Clusters II and $\mathrm{V}$, whereby the latter assigned a higher performance score $(M=3.16)$ on average than the former $(M=2.98)$. Likewise, the factor 'Augmented Services' was rated significantly different by Clusters I, II, IV and V. Clusters I $(M=3.36)$ and II $(M=3.20)$ on average rated the performance of this factors slightly better than Clusters IV $(M=2.56)$ and V $(M=2.75)$. The existence of significant differences between the clusters on the previously identified factors establishes the external validity of the chosen cluster solution. Singh (1990) suggests that a statistical comparison with a theoretically relevant variable not used to generate the cluster solution provides proof of external validity in segmentation studies (Singh, 1990).

\section{-TAKE IN TABLE 5-}

\subsection{Cluster Profiling by Demographic and Trip Characteristics}

Demographic characteristics such as age group $\left(\chi^{2}=17.28, \mathrm{p}>0.05\right)$, marital status $\left(\chi^{2}=9.80, p>0.05\right)$, nationality $\left(\chi^{2}=31.29, p>0.05\right)$, and educational level $\left(\chi^{2}=20.18, p>0.05\right)$ had no significant relationship with the clusters. This suggests that the GGA segments identified from this sample are homogeneous in terms of demographic characteristics. Trip characteristics 
such as previous stay $\left(\chi^{2}=5.91, \mathrm{p}>0.05\right)$, number of nights stayed $\left(\chi^{2}=10.72, \mathrm{p}>0.05\right)$, membership tenure $\left(\chi^{2}=4.64, \mathrm{p}>0.05\right)$ and purpose of visit $\left(\chi^{2}=14.59, \mathrm{p}>0.05\right)$ had no significant relationship with the clusters.

\section{Discussion and Implications}

The main objective of this study was to segment the most salient accommodation and service attributes for female travelers on a GGA trip. The results suggest the existence of five distinct segments within the GGA market that can be distinguished on the importance attached to different accommodation and service attributes. However, this market is homogeneous in their demographic and trip characteristics in the Malaysian context. These findings have several theoretical and managerial implications.

\subsection{Theoretical Implications}

The findings confirm non-academic research on the GGA market (AAA, 2007; Bond, 2007, 2011; Cavallari, 2008; Grout, 2003, 2005; Mastercard, 2005) that this segment is different from the general female leisure or business traveler due to their accommodation and service preferences. In terms of the importance and performance attached to various accommodation attributes, this study shows significant differences across the clusters. While safety and security is of general importance to the GGA market, there is nevertheless a segment (Cluster III-Food \& Beverage Driven) that assigns relatively low importance to this factor. Also, one segment (Cluster II- Safety \& Amenities Driven) assigns relatively higher importance to luxury bath products, sanitary items, manicure-related products, as well as bigger rooms. Research on the female leisure and business travel market emphasizes the high importance attributed to safety 
and security and low importance to female-specific amenities as strong determinants of accommodation choice (Lutz and Ryan, 1993; Sammons et al., 1999; Phadungyat, 2008). Four of the five segments identified in this study assigned high importance to safety and security with the segment, Food \& Beverage Driven (Cluster III) assigning relatively lower importance to this factor. One plausible explanation for this occurrence may be related to the notion of 'liberated self' (Yarnal \& Kerstetter, 2005) when traveling in groups. The physical, social, and emotional detachment from the day-to-day realities of home may translate into feelings of being more in control of life than at home and a sense of liberation normally absent from daily life (Yarnal \& Kerstetter, 2005; Yarnal, Kerstetter, Chick, \& Hutchinson, 2009). These authors showed in the context of cruise tourism that the presence of other group members provided a social and emotional safety net. The GGA market is strongly driven by motives such as friendship and bonding (Gibson et al., 2012), hence, social and emotional safety may be of more importance than physical safety for Cluster III.

In general, research on female accommodation preferences indicates that women business travelers do not place high importance on female-specific amenities (Lutz and Ryan, 1993; Sammons et al., 1999). However, Clusters II and V assigned relatively higher importance to amenities than other segments. These findings suggest that the GGA market is interested in the 'personal artifacts' (luxury bath products) and space/function (bigger room) of the physical environment of hotels (Walls, Okumus, Wang, \& Kwun, 2011). In the context of luxury hotels, Walls et al. (2011) noted that female travelers were specifically impacted by not only personal artifacts but also ambience and multi-sensory cues. The 'Personal Touch' factor identified in this 
study provides support to the importance of sensory cues (e.g. room smells nice) in hotel choice but was rated on average 'poor' in performance by three of the five clusters.

Food and beverage is an important aspect of guest satisfaction and loyalty to a hotel (Kandampully \& Suhartanto, 2000). Equally, it is well accepted that the presence of other people during food consumption has an influence on food intake (Klesges, Bartsch, Norwood, Kautzrnan, \& Haugrud, 1984). In social settings, friends and family often facilitate food consumption (Stroebele \& De Castro, 2004). It is therefore not surprising that two of the five clusters (Clusters III and V) assigned relatively high importance to food and beverage. One plausible explanation for this occurrence may be related to the symbolic aspects of food consumption (Kniazeva \& Venkatesh, 2007). When food consumption occurs in a setting involving other people, it becomes a key figure in establishing powerful interpersonal relationships (Kemmer, Anderson, \& Marshall, 1998; Yang, Khoo-Lattimore, \& Lai, 2014). In this role, food becomes a powerful way to connect people (Kniazeva and Venkatesh, 2007). This resonates well with the GGA market given that an important activity is dining out as part of the social and bonding experience (Bond, 2009; Grout, 2005).Yet, Clusters III and V are relatively neutral on the performance of hotels on the factor food and beverage.

Previous studies (e.g., Pennington-Gray and Kersetter, 2001) suggest that activities and entertainment are important to the female leisure travel market in general. This study suggests that bonding activities such as shopping, discounts for massages and spa treatments, and other activities that girlfriends can do together are of relatively higher importance to only specific segments of the GGA market (Clusters IV and V). For these women, activities that promote 
bonding between guests are important determinants of hotel choice. However, even though past studies have highlighted the prominence of friendship in the context of leisure (Hutchinson, Yarnal, Staffordson, \& Kerstetter, 2008; Son, Kerstetter, Yarnal, \& Baker, 2007) and tourism (Gibson et al., 2012), the women in Clusters I, II and III do not yet see how hotel amenities and services are promoting women friendships. This could be partly due to the perception and expectation of the hotel as primarily for accommodation rather than an extension of the social aspects of the holiday experience.

\subsection{Managerial Implications}

The findings have several implications for hotel managers and destination marketers. The high importance attached to safety and security by four of the five clusters suggests that safety is a hygiene factor in hotel choice for the GGA market. Not only should hotels be able to provide a safe and secure environment for female guests, but also provide specific facilities such as the availability of a direct dial to safety authorities to attract the GGA market in Malaysia. This attribute has not been previously identified as a salient attribute of hotel choice for female customers. Hotels could, for example, include a "security card" listing the telephone numbers of important local safety authorities for customers. Marketing the importance attached to safety and security by a hotel may serve as source of differentiation and positioning for hotels attempting to attract the GGA market.

It is also important to highlight that hotels do not have to invest heavily in room (re)design and amenities to attract the GGA market. It is a matter of customizing existing products and services, but also communicating these to the targeted group. For example, hotel 
and destination marketers should emphasize beyond safety and security attributes of the hotel, the quality of the amenities such as room size, availability of personalized products and personalized attention to service delivery. All segments identified in this study rated on average the performance of room amenities as 'poor'. This is an area of improvement for hotels, whereby the provision of, for example, high powered hair dryers, additional free bottles of water, and superior quality bath towels will improve perceptions of female customers interested in GGAs. Hotels may also have to position existing hotel amenities and facilities in such a way that they promote ideas of amenities and services facilitating customer 'bonding' and providing 'emotional safety’ to female customers.

In addition, the findings offer insights into improving current products and developing new products for the GGA market. The starting point for improving current products is the hotel attributes that were rated as below average on performance by GGA customers. Hotel room amenities, safety and security, personal touch and augmented services were all rated as relatively low in performance by all segments. While different segments of the market value these factors differently, it may be necessary for hotel managers to improve personal touch, for example, by better management of the sensorial aspects of the hotel experience. Using not only the visual, but also other aspects of the olfactory such as smell (e.g., pot-pourri in rooms and corridors), taste (e.g., food tasting menus in restaurant), and touch (e.g., use of different materials and textures in room and bathroom) to engage all the senses of the customer. Providing childcare facilities, offering healthy food options on menus and 24hr visible security personnel on site are other ways to differentiate the hotel offer for the GGA market. 
New product development can take the varied forms of girlfriend getaway packages. For example, a basic holiday package could include tailored products for women such as security cards, favorite branded toiletries, scent diffuser, magazines and DVDs. However, we emphasize that except for security cards, accommodation providers should be prepared to offer a range of amenities and facilities that female guests can choose from. A superior GGA package could take into account new room configuration or the use of suite rooms that facilitate group chats. At the very least, room design has to allow for several rooms to be connected. Within a GGA package, hotels could generate additional streams of revenue by facilitating bonding activities either within existing premises or in joint ventures with local businesses. Some examples could include wine and food/chocolate pairing workshops in the hotel restaurants to attract, for example, Cluster III (Food \& Beverage Driven). A possible holiday package for Cluster IV (Safety \& Activities Driven) could include private cabanas by the hotel pool with a snack and drinks hamper, private tours to specific local destinations (and these can be variedly themed according to such customers' interests for instance, adventure, sports, volunteering, food connoisseurs, culture and heritage), and cooking classes.

For hotel managers, Cluster V (Desirables) can be a particularly attractive segment given that they assigned high importance to all facets of the hospitality offer that can be tailored to female only customers. Hotels wanting to differentiate and position their hospitality offer from the mass market may be interested in this niche segment. Using communication and relationship marketing tactics, hotels may be able to capitalize on the loyalty of this segment by improving hotel amenities, food and beverage, safety and security, as well as providing an extensive range of female-only activities and entertainment. This segment could also be of interest to hotel 
developers that want to invest in facilities that are attractive to female customers other than business travelers.

\section{Limitations and Areas of Future Research}

The contributions of this study to the tourism and hospitality literature are two-fold: we identify salient accommodation and service attributes for the GGA market; and we show that the GGA market is heterogeneous in their accommodation and service preferences but homogeneous in their demographic characteristics. Despite these contributions, the study is not without limitations. First, the sample size falls short of the recently prescribed requirements for effective data driven segmentation (Dolnicar et al., 2014). The findings may need to be replicated with a larger sample size. Second, the GGA market was explored through a database of one hotel group. The hotel group is not necessarily representative of all female customers of the GGA market. Related to this is the homogeneity of the market on the basis of demographic and trip characteristics which is possibly contextual It would be necessary to extend this study by replicating it with female customers from other hotels in Malaysia but also customers from other countries to fully understand the GGA market. Specifically, replication in western countries such as USA, Australia and New Zealand may provide different insights into the accommodation and service preferences of this market. Third, while the list of items measured was extensive, it is possible that other items of importance may exist for this segment. Further qualitative research is recommended to understand not only accommodation preferences but also motivation, expectations and on-site behavior of this market. Fourth, hierarchical clustering methods are not without their own limitations (Dolnicar and Leisch, 2004). For more stable and reproducible clusters, future studies should employ other clustering techniques such as bagged clustering 
(Dolnicar \& Leisch, 2004; Prayag \& Hosany, 2014) and bi-clustering (Dolnicar, Yanamandram, \& Cliff, 2012).

Acknowledgement: This manuscript was prepared during scholarship funded by The Bureau of Educational and Cultural Affairs of the United States Department of State; and the MalaysianAmerican Commission on Educational Exchange under the Fulbright Visiting Scholar Award.

\section{References}

AAA. (2007). AAA Girlfriend Travel Research. Retrieved February 26, 2014, from AAA and Aspire $\quad$ http://aspiremarketing.com/girlfriend-getaway-report-conducted-by-aaa-andaspire-marketing/

Alamdari, F., \& Burrell, J. (2000). Marketing to female business travellers. Journal of Air Transportation World Wide, 5(2), 3-18.

Anon. (1997, May 13, 1997). Specially for female travelers. New Straits Times p. 21.

Anon. (2010, 22 September 2010). More Women Taking Girlfriend Getaway Vacations. Road \& Travel, 22, 1.

Ariffin, A. A. M., \& Maghzi, A. (2012). A preliminary study on customer expectations of hotel hospitality: Influences of personal and hotel factors. International Journal of Hospitality Management, 31(1), 191-198.

Bakewell, C., \& Mitchell, V.-W. (2003). Generation Y female consumer decision-making styles. International Journal of Retail \& Distribution Management, 31(2), 95-106.

Barlés-Arizón, M. J., Fraj-Andrés, E., \& Matute-Vallejo, J. (2010). Identification of the profiles of women who take holiday decisions. Tourism Review, 65(1), 4-17. 
Bond, M. (2007). A Woman's World Again: True Stories of World Travel. California: Solas House Inc.

Bond, M. (2009). Best Girlfriends Getaways in North America. Washington: National Geographic Society.

Bond, M. (2011). 50 Best Girlfriends Getaways in North America (Second ed.). Washington: National Geographic Society.

Cavallari, R. (2008, 19 May 2008). What women want: girlfriend getaways make up \$6-billion travel segment. Hotel and Motel Management, 8, 24.

Chiang, C.-Y., \& Jogaratnam, G. (2006). Why do women travel solo for purposes of leisure? Journal of Vacation Marketing, 12(1), 59-70.

Crompton, J. L., \& McKay, S. L. (1997). Motives of visitors attending festival events. Annals of Tourism Research, 24(2), 425-439.

Ćurcic, N., Zakic, L., \& Galantić, M. (2009). Segmentation of tourist markets - women as consumers Geographica Temisiensis, 19(1-2), 67-74.

Dolnicar, S. (2002). A review of data-driven market segmentation in tourism. Journal of Travel \& Tourism Marketing, 12(1), 1-22.

Dolnicar, S. (2007). Market Segmentation in Tourism. In A. Woodside \& D. Martin (Eds.), Tourism Management: Analysis, Behaviour, and Strategy (pp. 129-146). Oxforshire, UK: CABI.

Dolničar, S. (2004). Beyond "commonsense segmentation": A systematics of segmentation approaches in tourism. Journal of Travel Research, 42(3), 244-250.

Dolnicar, S., \& Grün, B. (2008). Challenging "Factor-Cluster Segmentation”. Journal of Travel Research, 47(1), 63-71. 
Dolnicar, S., Grün, B., Leisch, F., \& Schmidt, K. (2014). Required Sample Sizes for Data-Driven Market Segmentation Analyses in Tourism. Journal of Travel Research, 53(3), 296-306.

Dolnicar, S., \& Leisch, F. (2004). Segmenting markets by bagged clustering. Australasian Marketing Journal (AMJ), 12(1), 51-65.

Dolnicar, S., Yanamandram, V., \& Cliff, K. (2012). The contribution of vacations to quality of life. Annals of Tourism Research, 39(1), 59-83.

Dubé, L., \& Morgan, M. S. (1998). Capturing the dynamics of in-process consumption emotions and satisfaction in extended service transactions. International Journal of Research in Marketing, 15(4), 309-320.

Eid, R., \& El-Gohary, H. (2015). The role of Islamic religiosity on the relationship between perceived value and tourist satisfaction. Tourism Management, 46, 477-488.

Euromonitor. (2010). Future watch: Will the flourishing trend of female-friendly products continue into the next few years? . Retrieved 8 August 2014, from Euromonitor International $\quad$ http://blog.euromonitor.com/2010/04/future-watch-will-the-flourishingtrend-of-femalefriendly-products-continue-into-the-next-few-years.html

Foster, N., \& Botterill, D. (1995). Hotels and the businesswoman: A supply-side analysis of consumer dissatisfaction. Tourism Management, 16(5), 389-393.

Friesen, T. (2013). Five affordable (and 2 splurge-worthy) girlfriend getaways. Retrieved 4 August $2014 \quad$ http://www.fodors.com/news/girlfriend-trips-and-bachelorette-partydestinations-6531.html

Frochot, I., \& Morrison, A. M. (2001). Benefit segmentation: A review of its applications to travel and tourism research. Journal of Travel \& Tourism Marketing, 9(4), 21-45. 
Gentle, N. (2012). The 2012 Female Travel and Lifestyle Report. Retrieved 10 March 2014 www.lastminute.com

Getaways, G. (2008, 1 January 2008). Girlfriend Getaways: Single issue magazine.

Gibson, H. J., Berdychevsky, L., \& Bell, H. L. (2012). Girlfriend getaways over the life course: change and continuity. Annals of Leisure Research, 15(1), 38-54.

Glover, T. D., \& Parry, D. C. (2008). Friendships developed subsequent to a stressful life event: the interplay of leisure, social capital, and health. Journal of Leisure Research, 40(2), 208-230.

Graburn, N. H. (1983). The anthropology of tourism. Annals of Tourism Research, 10(1), 9-33.

Green, E. (1998). 'Women doing friendship’: an analysis of women's leisure as a site of identity construction, empowerment and resistance. Leisure studies, 17(3), 171-185.

Grout, P. (2003). Girlfriend Getaways: You Go Girl! And I'll Go, Too. Connecticut, USA: The Globe Pequot Press.

Grout, P. (2005). Girlfriend Getaways: You Go Girl! And I'll Go, Too (Second ed.). Connecticut, USA: The Globe Pequot Press.

Harranek, C. (2014). 15 top girlfriend getaways. Retrieved 8 September 2014 http://www.frommers.com

Harris, C., \& Ateljevic, I. (2003). Perpetuating the male gaze as the norm: challenges for'her'participation in business travel. Tourism Recreation Research, 28(2), 21-30.

Harris, C., \& Wilson, E. (2005). Leaving home: pre-travel strategies used by female business and pleasure tourists. Paper presented at the CAUTHE 2005: Sharing Tourism Knowledge, Alice Springs. N.T., Australia. 
Heimtun, B. (2012). The friend, the loner and the independent traveller: Norwegian midlife single women's social identities when on holiday. Gender, Place \& Culture, 19(1), 83101.

Hutchinson, S. L., Yarnal, C. M., Staffordson, J., \& Kerstetter, D. L. (2008). Beyond fun and friendship: The Red Hat Society as a coping resource for older women. Ageing and Society, 28(07), 979-999.

Jennings, G. R. (2005). Caught in the irons: One of the lived experiences of long-term ocean cruising women. Tourism Review International, 9(2), 177-193.

Jordan, F., \& Gibson, H. (2005). "We're not stupid...but we'll not stay at home either": experiences of solo women travellers. Tourism Review International, 9(2), 195-211.

Kandampully, J., \& Suhartanto, D. (2000). Customer loyalty in the hotel industry: the role of customer satisfaction and image. International journal of contemporary hospitality management, 12(6), 346-351.

Kasanicky, L. (2009). The Complete Idiot's Guide to Girlfriend Getaways. New York: Penguin Books.

Kemmer, D., Anderson, A. S., \& Marshall, D. W. (1998). The marriage menu: Life, food and diet in transition. In A. Murcott (Ed.), The nation's diet: The social science of food choice (pp. 197-209). London, UK: Longman.

Kent, M. (2010). Women control over \$20 trillion in world-wide spending. Retrieved 10 April 2014 http://www.coca-colacompany.com/topics/business

Kerstetter, D., \& Pennington-Gray, L. (1999). Decision-making roles adopted by universityeducated women who travel for pleasure. Journal of Hospitality \& Leisure Marketing, 6(3), 23-39. 
Khan, S. (2011). Gendered leisure: Are women more constrained in travel for leisure. Tourismos: An International Multidisciplinary. Journal of Tourism, 6(1), 105-121.

Kim, S. S., \& Prideaux, B. (2005). Marketing implications arising from a comparative study of international pleasure tourist motivations and other travel-related characteristics of visitors to Korea. Tourism Management, 26(3), 347-357.

Kleiber, D. A., Hutchinson, S. L., \& Williams, R. (2002). Leisure as a resource in transcending negative life events: Self-protection, self-restoration, and personal transformation. Leisure Sciences, 24(2), 219-235.

Klesges, R. C., Bartsch, D., Norwood, J. D., Kautzrnan, D., \& Haugrud, S. (1984). The effects of selected social and environmental variables on the eating behavior of adults in the natural environment. International Journal of Eating Disorders, 3(4), 35-41.

Kniazeva, M., \& Venkatesh, A. (2007). Food for thought: A study of food consumption in postmodern US culture. Journal of consumer behaviour, 6(6), 419-435.

Kruger, M., Saayman, M., \& Ellis, S. (2011). Segmentation by genres: the case of the Aardklop National Arts Festival. International Journal of Tourism Research, 13(6), 511-526.

Laing, K., \& Butterfield, E. (2002). Girlfriends' getaway: A complete guide to the weekend adventure that turns friends into sisters Colorado Springs, Colorado: Waterbrook Press.

Lenskyj, H. J. (1994). Sexuality and femininity in sport contexts: issues and alternatives. Journal of Sport and Social Issues, 18(4), 356-376.

Loh, P. (2009). For women only: The exclusive ladiesonly floor at Thistle Johor Bahru. Retrieved 10 April 2014 http://www.travelific.my/travelstry_full.php

Lounsbury, J. W., \& Hoopes, L. L. (1988). Five-year stability of leisure activity and motivation factors. Journal of Leisure Research. 
Lutz, J., \& Ryan, C. (1993). Hotels and the businesswoman: An analysis of businesswomen's perceptions of hotel services. Tourism Management, 14(5), 349-356.

Mastercard. (2005). Women travellers of Asia Pacific: a new powerhouse. Retrieved 20 $\begin{array}{llll}\text { September 2014, } & \text { from } & \text { Mastercard } & \text { International }\end{array}$ http://www.mastercard.com/cn/wce/PDF/insights/2005/1st_Quarter/Insights_Women_V4 _en.pdf

Mattila, A. S. (2000). The impact of culture and gender on customer evaluations of service encounters. Journal of Hospitality \& Tourism Research, 24(2), 263-273.

McCleary, K. W., Weaver, P. A., \& Lan, L. (1994). Gender-based differences in business travelers' lodging preferences. Cornell Hotel and Restaurant Administration Quarterly, 35(2), 51-58.

McDaniel, S. R., \& Kinney, L. (1998). The implications of recency and gender effects in consumer response to ambush marketing. Psychology \& Marketing, 15(4), 385-403.

McGehee, N. G., Loker-Murphy, L., \& Uysal, M. (1996). The Australian international pleasure travel market: motivations from a gendered perspective. Journal of Tourism Studies, 7(1), 45-57.

McNamara, K. E., \& Prideaux, B. (2010). A typology of solo independent women travellers. International Journal of Tourism Research, 12(3), 253-264.

Mieczkowski, Z. (1990). World trends in tourism and recreation (Vol. 3). New York: American University Studies.

Morrison, A. M. (1996). Hospitality and travel marketing. Albany, USA: Delmar Publishers.

Newth, F. (2011). The newstrategic imperative: Understanding the female business traveler. International Business \& Economics Research Journal (IBER), 8(11). 
Nichols, C. M., \& Snepenger, D. J. (1988). Family decision making and tourism behavior and attitudes. Journal of Travel Research, 26(4), 2-6.

Park, D.-B., \& Yoon, Y.-S. (2009). Segmentation by motivation in rural tourism: A Korean case study. Tourism Management, 30(1), 99-108.

Pennington-Gray, L. A., \& Kerstetter, D. L. (2001). What do university-educated women want from their pleasure travel experiences? Journal of Travel Research, 40(1), 49-56.

Phadungyat, P. (2008). Factors influencing the selection of serviced apartments by female business travellers. (Master of Arts ), Srinakharinwirot University, Thailand.

Prayag, G. (2010). Images as pull factors of a tourist destination: A factor-cluster segmentation analysis. Tourism Analysis, 15(2), 213-226.

Prayag, G. (2012). Paradise for who? Segmenting visitors' satisfaction with cognitive image and predicting behavioural loyalty. International Journal of Tourism Research, 14(1), 1-15.

Prayag, G., \& Hosany, S. (2014). When Middle East meets West: Understanding the motives and perceptions of young tourists from United Arab Emirates. Tourism Management, 40, 3545.

Pritchard, A., \& Morgan, N. J. (2000). Privileging the male gaze: Gendered tourism landscapes. Annals of Tourism Research, 27(4), 884-905.

Sammons, G., Moreo, P., Benson, L. F., \& Demicco, F. (1999). Analysis of female business travelers' selection of lodging accommodations. Journal of Travel \& Tourism Marketing, 8(1), 65-83.

Sarigöllü, E., \& Huang, R. (2005). Benefits segmentation of visitors to Latin America. Journal of Travel Research, 43(3), 277-293. 
Sham, R., Soltani, S. H. K., Sham, M., \& Mohamed, S. (2012). Travel safety fear factor among vulnerable group of travelers: the urban scenario. Procedia-Social and Behavioral Sciences, 50, 1033-1042.

Shim, S., \& Kotsiopulos, A. (1993). A typology of apparel shopping orientation segments among female consumers. Clothing and textiles research journal, 12(1), 73-85.

Silverstein, M. J., \& Sayre, K. (2009). The female economy. Harvard Business Review, 87(9), 46-53.

Smith, W. W., \& Carmichael, B. A. (2007). Domestic business travel in Canada with a focus on the female market. Journal of Travel \& Tourism Marketing, 21(1), 65-76.

Son, J. S., Kerstetter, D. L., Yarnal, C. M., \& Baker, B. L. (2007). Promoting older women's health and well-being through social leisure environments: What we have learned from the Red Hat Society®. Journal of Women \& Aging, 19(3-4), 89-104.

Stone, G. J., \& Nichol, S. (1999). Older, single female holidaymakers in the United KingdomWho needs them? Journal of Vacation Marketing, 5(1), 7-17.

Stroebele, N., \& De Castro, J. M. (2004). Effect of ambience on food intake and food choice. Nutrition, 20(9), 821-838.

Tai, S. H., \& Tam, J. L. (1997). A lifestyle analysis of female consumers in greater China. Psychology and Marketing, 14(3), 287-307.

Tkaczynski, A., \& Rundle-Thiele, S. (2010). Event segmentation: A research agenda. Tourism Management,

32(2), 426-434. 
Tuma, M. N., Decker, R., \& Scholz, S. (2011). A survey of the challenges and pitfalls of cluster analysis application in market segmentation. International Journal of Market Research, 53(3).

Vellas, F., \& Becherel, L. (1999). International marketing of travel and tourism: a strategic approach. Basingstoke, UK: Macmillan Press Ltd.

Walls, A. R., Okumus, F., Wang, Y. R., \& Kwun, D. J.-W. (2011). An epistemological view of consumer experiences. International Journal of Hospitality Management, 30(1), 10-21.

Ward, T. (2013). America's best girlfriend getaways. Retrieved 7 September 2014 http://www.travelandleisure.com/articles/americas-best-girlfriend-getaways

Weaver, D., \& Oppermann, M. (2000). Tourism Management. Milton, Australia: John Wiley and Sons.

Westwood, S., Pritchard, A., \& Morgan, N. J. (2000). Gender-blind marketing: Businesswomen's perceptions of airline services. Tourism Management, 21(4), 353-362.

Wilkeming, D. (2007). Poll finds new trends in girls getaways. Retrieved 9 September 2014 www.travelmole.com

Wilson, E., \& Harris, C. (2006). Meaningful travel: women, independent travel and the search for self and meaning. Tourism (Zagreb), 54(2), 161-172.

Wilson, E., \& Little, D. E. (2005). A “relative escape”? The impact of constraints on women who travel solo. Tourism Review International, 9(2), 155-175.

Wilson, E., \& Little, D. E. (2008). The solo female travel experience: Exploring the 'geography of women's fear'. Current Issues in Tourism, 11(2), 167-186. 
Yang, C. L., Khoo-Lattimore, C., \& Lai, M. Y. (2014). Eat to Live or Live to Eat? Mapping Food and Eating Perception of Malaysian Chinese. Journal of Hospitality Marketing \& Management(ahead-of-print), 1-22.

Yarnal, C. M., \& Kerstetter, D. (2005). Casting off an exploration of cruise ship space, group tour behavior, and social interaction. Journal of Travel Research, 43(4), 368-379.

Yarnal, C. M., Kerstetter, D., Chick, G., \& Hutchinson, S. (2009). The Red Hat Society®: An Exploration of Play and Masking in Older Women’s Lives. From Children to Red Hatters: Diverse Images and Issues of Play, 144-165. 
Table 1: Demographic and Trip Characteristics of Sample

\begin{tabular}{|c|c|c|c|c|c|c|}
\hline \multicolumn{3}{|l|}{ Demographics } & $\%$ & \multicolumn{2}{|l|}{ Trip Characteristics } & $\%$ \\
\hline \multirow{6}{*}{ Age } & \multicolumn{2}{|c|}{ 18-20 years old } & 8.60 & Main purpose of trip & Leisure & 51.4 \\
\hline & \multicolumn{2}{|c|}{ 21-30 years old } & 25.7 & & Socialization & 33.5 \\
\hline & \multicolumn{2}{|c|}{ 31-40 years old } & 16.6 & & Bonding & 5.00 \\
\hline & \multicolumn{2}{|c|}{ 31-40 years old } & 13.9 & & Other & 10.1 \\
\hline & \multicolumn{2}{|c|}{$41-50$ years old } & 22.7 & & & \\
\hline & \multicolumn{2}{|c|}{ 51-60 years old } & 12.5 & & & \\
\hline \multirow{7}{*}{ Nationality } & \multicolumn{2}{|l|}{ Malaysian } & 54.7 & Membership tenure & $<1$ year & 7.00 \\
\hline & \multirow{2}{*}{\multicolumn{2}{|c|}{$\begin{array}{l}\text { Singaporean } \\
\text { Indian }\end{array}$}} & 22.5 & & $1-2$ years & 13.9 \\
\hline & & & 6.60 & & $>2$ years & 79.1 \\
\hline & \multicolumn{2}{|l|}{ Indonesian } & 5.20 & & & \\
\hline & \multicolumn{2}{|l|}{ Chinese } & 5.50 & & & \\
\hline & \multicolumn{2}{|l|}{ Thai } & 3.10 & & & \\
\hline & \multicolumn{2}{|l|}{ Others } & 2.40 & & & \\
\hline \multirow[t]{2}{*}{ Marital Status } & \multicolumn{2}{|l|}{$\begin{array}{l}\text { Single } \\
\text { Married }\end{array}$} & $\begin{array}{l}44.7 \\
43.5\end{array}$ & No. of nights & $\begin{array}{l}\text { 1-3 nights } \\
4-6 \text { nights }\end{array}$ & $\begin{array}{c}89.50 \\
6.20\end{array}$ \\
\hline & \multicolumn{2}{|c|}{ Separated/ Divorced } & 11.8 & & $>6$ nights & 4.30 \\
\hline \multirow[t]{4}{*}{ Education Level } & $\begin{array}{l}\text { Completed } \\
\text { Education }\end{array}$ & & 14.6 & $\begin{array}{l}\text { Previous stay in hotel } \\
\text { group }\end{array}$ & & 96.90 \\
\hline & $\begin{array}{l}\text { Completed } \\
\text { Education }\end{array}$ & Secondary & 32.4 & & No & 2.80 \\
\hline & \multirow{2}{*}{\multicolumn{2}{|c|}{$\begin{array}{l}\text { Graduate Degree Education } \\
\text { Post Graduate Degree } \\
\text { Others }\end{array}$}} & 37.0 & & Don't know & 0.30 \\
\hline & & & $\begin{array}{l}13.6 \\
2.40\end{array}$ & & & \\
\hline
\end{tabular}


Table 2: Cluster of Accommodation and Service Preferences

\begin{tabular}{|c|c|c|c|c|c|}
\hline Accommodation and Service Preferences & $\begin{array}{c}\text { Cluster } \\
\text { I }\end{array}$ & $\begin{array}{c}\text { Cluster } \\
\text { II }\end{array}$ & $\begin{array}{c}\text { Cluster } \\
\text { III }\end{array}$ & $\begin{array}{c}\text { Cluster } \\
\text { IV }\end{array}$ & $\begin{array}{c}\text { Cluster } \\
\text { V }\end{array}$ \\
\hline Safety and Security (mean) & 4.24 & 4.31 & 2.98 & 4.32 & 4.40 \\
\hline Item 1: Hotel offers secure lifts and floor access & 4.37 & 4.48 & 3.01 & 4.37 & 4.63 \\
\hline $\begin{array}{l}\text { Item 2: Hotel offers female only staff from } \\
\text { housekeeping to room service }\end{array}$ & 3.61 & 3.68 & 2.51 & 3.77 & 3.80 \\
\hline Item 3: Hotel has brightly lit parking area & 4.56 & 4.62 & 3.35 & 4.61 & 4.61 \\
\hline $\begin{array}{l}\text { Item 4: Hotel has a direct dial to security/police/safety } \\
\text { authorities }\end{array}$ & 4.43 & 4.44 & 3.05 & 4.52 & 4.59 \\
\hline Room Amenities (mean) & 2.28 & 3.52 & 2.96 & 2.60 & 3.98 \\
\hline $\begin{array}{l}\text { Item 5: Hotel offers a bigger room for female } \\
\text { customers }\end{array}$ & 3.56 & 2.05 & 2.84 & 3.19 & 2.85 \\
\hline Item 6: Room has ironing board and steam iron & 2.13 & 3.72 & 2.96 & 2.38 & 4.25 \\
\hline Item 7: Room has full body mirror & 1.93 & 3.72 & 2.96 & 2.40 & 4.29 \\
\hline Item 8: Room has dressing mirror with white light & 2.01 & 3.99 & 3.49 & 2.60 & 4.41 \\
\hline $\begin{array}{l}\text { Item 9: Hotel offers branded amenities and luxury bath } \\
\text { products }\end{array}$ & 2.22 & 3.81 & 2.68 & 2.12 & 3.73 \\
\hline $\begin{array}{l}\text { Item 10: Hotel offers luxury feminine toiletries (e.g. } \\
\text { nail polish, nail polish remover) }\end{array}$ & 1.94 & 3.84 & 3.13 & 2.86 & 4.38 \\
\hline Item 11: Room has sanitary pads & 2.14 & 3.54 & 2.65 & 2.68 & 3.97 \\
\hline Food and Beverage (mean) & 2.98 & 2.55 & 3.01 & 2.98 & 3.10 \\
\hline $\begin{array}{l}\text { Item 12: Hotel offers healthy options in restaurant } \\
\text { menu }\end{array}$ & 3.07 & 2.36 & 3.07 & 2.80 & 2.92 \\
\hline $\begin{array}{l}\text { Item 13: Hotel offers Food and Beverage Lounge and } \\
\text { Snack Menu on dedicated floor }\end{array}$ & 2.90 & 2.73 & 2.95 & 3.15 & 3.27 \\
\hline Activities and Entertainment (mean) & 2.40 & 2.32 & 2.71 & 3.47 & 3.49 \\
\hline $\begin{array}{l}\text { Item 14: Hotel offers activities that female guests can } \\
\text { do together }\end{array}$ & 2.91 & 2.67 & 3.36 & 2.33 & 3.33 \\
\hline Item 15: Hotel offers shopping vouchers and discounts & 2.57 & 2.46 & 2.50 & 3.73 & 3.59 \\
\hline $\begin{array}{l}\text { Item 16: Hotel offers discounts for massages and spa } \\
\text { treatments }\end{array}$ & 2.16 & 1.94 & 2.86 & 3.79 & 4.03 \\
\hline $\begin{array}{l}\text { Item 17: Hotel offers free transport to nearby shopping } \\
\text { malls }\end{array}$ & 2.18 & 2.00 & 2.53 & 3.88 & 3.48 \\
\hline $\begin{array}{l}\text { Item 18: Hotel organizes bonding activities with } \\
\text { girlfriends (e.g. lunch, dinner or pool chats) }\end{array}$ & 2.19 & 2.56 & 2.28 & 3.60 & 3.04 \\
\hline
\end{tabular}


Table 3: Discriminant Analysis Results

\begin{tabular}{|l|c|c|c|c|}
\hline Accommodation and Service attributes & DF1 & DF2 & DF3 & DF4 \\
\hline Item 8 & $.548^{*}$ & -.171 & -.108 & .056 \\
Item 7 & $.495^{*}$ & -.134 & .001 & .218 \\
Item 10 & $.483^{*}$ & -.042 & -.012 & -.068 \\
Item 6 & $.425^{*}$ & -.147 & .021 & .302 \\
Item 9 & $.333^{*}$ & -.262 & .111 & .149 \\
Item 11 & $.328^{*}$ & -.046 & .085 & .057 \\
Item 16 & .206 & $.609^{*}$ & -.178 & .243 \\
Item 17 & .125 & $.570^{*}$ & -.062 & -.151 \\
Item15 & .088 & $.338^{*}$ & .044 & -.004 \\
Item 4 & .039 & .115 & $.649^{*}$ & .150 \\
Item 1 & .073 & .055 & $.633^{*}$ & .243 \\
Item 3 & .023 & .061 & $.594^{*}$ & .041 \\
Item2 & .038 & .086 & $.418^{*}$ & .049 \\
Item 14 & .041 & -.048 & -.154 & $.551^{*}$ \\
Item 5 & -.185 & .187 & -.030 & $.467^{*}$ \\
Item 18 & .101 & .281 & .073 & $-.434^{*}$ \\
Item 12 & -.060 & .069 & -.093 & $.319^{*}$ \\
Item 13 & .024 & .100 & -.022 & $.114^{*}$ \\
\hline Eigenvalue & 3.28 & 1.58 & .64 & .17 \\
\% of variance explained & 57.90 & 27.90 & 11.20 & 2.90 \\
Canonical correlation & $.88^{\mathrm{a}}$ & $.78^{\mathrm{a}}$ & $.62^{\mathrm{a}}$ & $.38^{\mathrm{a}}$ \\
Wilk's Lambda & .05 & .20 & .52 & .86 \\
\hline *significant loadings, a=p $<0.01$ & & & & \\
\hline
\end{tabular}


Table 4: Factor Analysis of Hotel Performance Attributes

\begin{tabular}{|c|c|c|c|c|c|}
\hline \multirow[b]{2}{*}{ Hotel Performance Attributes } & \multicolumn{5}{|l|}{ Factors } \\
\hline & F1 & F2 & F3 & F4 & F5 \\
\hline Room has high powered hair dryers & .845 & -.006 & .027 & -.101 & -.042 \\
\hline Room has comfortable mattress and pillows & .833 & -.046 & .042 & -.030 & -.018 \\
\hline Room provides additional bottles of drinking water & .815 & .030 & -.038 & .093 & .010 \\
\hline Hotel offers superior quality bath towels & .779 & .001 & -.061 & .213 & -.004 \\
\hline Room offered with fresh fruits & .736 & .093 & -.010 & 188 & .073 \\
\hline Hotel has 24hour visible security personnel on duty & .016 & 878 & .031 & .033 & -.008 \\
\hline Hotel has safety deposit boxes & .015 & 878 & .025 & -.010 & .009 \\
\hline Hotel notifies you before room delivery service & .024 & .863 & .046 & .000 & .025 \\
\hline Hotel offers healthy options in room-service menu & .067 & -.005 & .938 & -.078 & -.015 \\
\hline Hotel offers a good breakfast buffet & .052 & .007 & .924 & -.094 & -.011 \\
\hline Hotel offers 24 hour restaurant and coffee shop & -.127 & .093 & .729 & -.062 & -.014 \\
\hline Room smells nice & .042 & -.030 & -.128 & .854 & -.001 \\
\hline Room has a personal welcome note & .201 & .051 & -.081 & .845 & .012 \\
\hline Hotel offers childcare services & .008 & -.021 & -.005 & -.036 & .870 \\
\hline $\begin{array}{l}\text { Hotel offers loyalty cards with added value (e.g. } \\
\text { discount on next stay or packaged hotel offers) }\end{array}$ & .002 & .044 & -.029 & .047 & .865 \\
\hline Eigenvalue & 3.29 & 2.31 & 2.30 & 1.57 & 1.51 \\
\hline$\%$ of variance explained & 21.91 & 15.41 & 15.34 & 10.44 & 10.10 \\
\hline Cronbach's alpha & 0.91 & 0.86 & 0.85 & 0.72 & 0.74 \\
\hline
\end{tabular}


Table 5: ANOVA Results on Hotel Performance Attributes

\begin{tabular}{|l|c|c|c|c|c|}
\hline Cluster/Factor & $\begin{array}{c}\text { F1: Hotel } \\
\text { Room } \\
\text { Amenities }\end{array}$ & $\begin{array}{c}\text { F2: Safety } \\
\text { and } \\
\text { Security }\end{array}$ & $\begin{array}{c}\text { F3: Food } \\
\text { and } \\
\text { Beverage }\end{array}$ & $\begin{array}{c}\text { F4: } \\
\text { Personal } \\
\text { Touch }\end{array}$ & $\begin{array}{c}\text { F5: } \\
\text { Augmented } \\
\text { Services }\end{array}$ \\
\hline Cluster I (Safety Conscious) & 2.56 & 2.75 & 3.00 & 2.82 & 3.36 \\
\hline Cluster II (Safety \& Amenities Driven) & 2.10 & 2.87 & 2.98 & 2.49 & 3.20 \\
\hline Cluster III (Food \& Beverage Driven) & 2.21 & 2.24 & 3.06 & 3.13 & 3.25 \\
\hline $\begin{array}{l}\text { Cluster IV (Safety \& Activities } \\
\text { Driven) }\end{array}$ & 2.44 & 2.92 & 3.33 & 2.87 & 2.56 \\
\hline Cluster V (Desirables) & 2.24 & 2.97 & 3.16 & 3.08 & 2.75 \\
\hline F & 4.91 & 3.31 & 1.64 & 3.88 & 5.80 \\
\hline Sig. & .001 & .011 & .162 & .004 & .000 \\
\hline & $\begin{array}{c}\text { Clusters I } \\
\& \text { II* }\end{array}$ & $\begin{array}{c}\text { Clusters III } \\
\& \text { IV* } \\
\text { Clusters III } \\
\& V^{*}\end{array}$ & & $\begin{array}{c}\text { Clusters II } \\
\& \text { V* }\end{array}$ & $\begin{array}{c}\text { Clusters I \& } \\
\text { IV* Clusters I } \\
\& \text { V* Clusters } \\
\text { II \& IV* }\end{array}$ \\
\hline \\
Post-Hoc Test
\end{tabular}

